\title{
THE JUNCTURE OF EVOLUTIONARY AND DEVELOPMENTAL BIOLOGY
}

\author{
Elihu M. Gerson \\ gerson@ieee.org \\ http://tremont.typepad.com/technical_work
}

31 October 2003

Forthcoming in a collection of papers edited by Jane Maienschein and Manfred Laubichler. Revised version of a paper presented at the Dibner Institute Conference on Evolutionary and Developmental Biology, Cambridge, MA, October, 2002. I am grateful to James R. Griesemer, Jan Sapp, William C. Wimsatt, and Rasmus G. Winther for many helpful discussions over the years, and to Manfred Laubichler and Jane Maienschein for helpful comments on earlier drafts. I am grateful to M. Sue Gerson for continuing support.

Tremont Research Institute 458 Twenty-Ninth Street San Francisco, CA 94131 


\section{THE JUNCTURE OF EVOLUTIONARY AND DEVELOPMENTAL BIOLOGY}

In their collection of papers on the history of evolution research, Mayr and Provine ${ }^{1}$ make clear that the Modern Synthesis which has formed the core of evolutionary research since the 1940's did not include any significant participation from students of development. The history of developmental research in the same period shows an equal lack of interest on the part of developmental biologists with evolutionary concerns. ${ }^{2}$ The last generation however, has seen the extraordinary success of a new intersection between development and evolution research. This connection, tentative and fragile in the late 1970s, has grown to become one of the most productive and intense areas of research in the life sciences. This paper addresses several questions about that connection: How did the separation of the two lines of research come about? What happened to bring them back together? How can we think about this kind of intersection analytically, in a way useful to scientists as well as science studies scholars?

My approach to these questions is analytic, synoptic, and organizational. Rather than attempting a detailed narrative of events in many specialties over many decades, I focus on the long-term pattern of relationships among lines of research in comparative biology. My primary concern here is to sketch a way of understanding the growth and decay and regrowth of connections among lines of research. I focus on lines of work because they are the hinge of events: simultaneously part of both the intellectual work and its relations with the rest of society.

Changes in the large-scale pattern of institutions over the last century have facilitated some ways of doing research and hindered others. One result of this process was the separation of evolutionary and developmental research early in the 20th century, followed by their reconnection and intersection in the last generation. This paper sketches some (only some) of the more salient institutional trends in this process; I have provided a more detailed analysis of the American case elsewhere. In particular, I shall focus on four factors. First, research at the end of the nineteenth century ran up against the limits in the capacities of the available research technology, making it difficult or impossible to address important questions. Second, the organization of many institutions (including science and academia) was strongly rationalized (i.e., arranged with economic efficiency in mind) in the first half of 
the twentieth century. This process facilitated some aspects of research, and retarded others. One side-effect of this process was to encourage a split between research on development and research on evolution. Third, some styles of research-i.e., strategies for making large-scale decisions- became more prevalent, while others declined. The effect was to reinforce the rationalizing trend and accelerate the division between development and evolution research. Finally, certain changes in the concepts used by scientists in both fields facilitated the intersection of the two fields late in the 20th century.

\section{Historical background: Evolution and development together at first}

The point of 19th century natural history was not merely ever-finer description, but the analysis of connections among the parts of nature. This was accomplished by comparing across patterns of different kinds (morphological, developmental, geographical, paleontological), and inferring classifications and relationships among classifications. Darwin's hypothesis of descent with modification was the most important of these relationships, because it tied together so many different kinds of evidence. The analysis of descent relationships (phylogeny) was a major part of the research stimulated by Darwin's theory. Darwin's argument relied heavily on geographic, morphological, and paleontological evidence, but the connection with developmental concerns was quickly drawn. Especially in Germany, the work of Muller, Haeckel, and their followers (adapting an established tradition of morphological work) provided a close tie between comparative embryology and the study of phylogeny. ${ }^{4}$ Similarity among developmental patterns was especially important because early stages of development gave a great deal of information about relationships which was otherwise unobtainable. The idea that developmental sequence reflects the phylogenetic history of the species (the "biogenetic law") was the centerpiece of this work. A similar program of research grew up in England. ${ }^{5}$

Through the late nineteenth century, the focus of morphological attention shifted from major organ systems to single organs to cells to parts of cells. At the same time, the focus of taxonomic attention shifted from classes and orders to species, sub-species, and varieties. Similarly, the focus of attention in stratigraphy (hence, paleontology) shifted from eras to periods to ages. A similar pattern thus characterized work in all the kinds of phenomena studied by naturalists. Their focus was increasingly on detecting ever smaller differences and interpreting their significance. 
At the end of the nineteenth century, this mode of comparative research ran into difficulties. In order to make progress, scientists had to look earlier and earlier in development, specify more profound morphological characters, deal with smaller and smaller taxonomic groups, and look earlier and earlier in the rocks for paleontological specimens. Each succeeding round of research became more difficult to manage technically, and correspondingly more expensive to organize and manage. The progress of research on inheritance, for example, indicated that morphological features were controlled at the subcellular level. By the end of the century, these difficulties had reached a crisis. Limits of technology made it almost impossible to detect very small differences. Microscopy, for example, was inadequate to examine the microstructure of events surrounding fertilization and the earliest stages of growth. Again, fossils rarely preserved the fine morphological detail needed to make fine taxonomic distinctions. Moreover, the chain of homologous inferences from one classification to another became very long, and hence there was great room for argument over interpretations. In consequence, the strategy seemed to fail just where it was used to address the most general and important questions, e.g., what are the relationships among the major groups of arthropods? What is the phyletic origin of the vertebrates? ${ }^{6}$ As a result of these difficulties, many scientists began to focus on other problems. William Bateson, for example, simply threw up his hands and decided to study variation. ${ }^{7}$

\section{Segmenting evolutionary continuity and developmental continuity}

The prevalent view of evolution in the late 19th century was that evolution converts similarity and continuity into difference and diversity via adaptation. In this view, adaptation is about the relationships among parts of nature. This included the fit among parts of the body vis-à-vis one another, and vis-à-vis the environment. It also included the fit of species vis-à-vis each other via behavior and community structure. This view puts morphological and developmental concerns at the heart of evolutionary thought, and made significant room for ecological and behavioral considerations as well. For example, Haeckel's vision (as captured in the biogenetic law) focused on similarity among different kinds of continuityphylogeny and ontogeny were together part of a larger process. This construed ontogeny as a consequence or epiphenomenon of phylogeny. There was thus an intimate connection 
between the development of individuals and the succession of generations, which rested on material continuity.

In this view, inheritance (i.e., heredity and development together) were about the preservation (re-production) of similarity across generations. Lineage and genealogy (succession of generations) were the chief categories for thinking about what lay between individual organisms and species. Evolutionary morphology was thus crucially about partwhole relationships and how they change. For many, even inheritance was about part-whole relations (i.e., genealogy), even after the rediscovery of Mendel in 1900. Alternative approaches to development in the late 19th century began to focus on mechanical explanations of development. ${ }^{8}$ This approach emphasized development rather than phylogeny, and the search for efficient and material causes, rather than formal and final ones. This difference in emphasis had the effect of starting a wedge between studies of development and studies of evolution.

In the 20th century this split widened in important ways. In the 19th century, Weismann's distinction between germplasm and somatoplasm fostered a conceptual separation between generations on the one hand ("sequestration of germ plasm") and ontogeny on the other. ${ }^{9}$ This relatively mild distinction was picked up in the US and converted into "Weismannism", which black-boxed the life-cycle as irrelevant to transmission. ${ }^{10}$ The effect was to create a much deeper division between development and transmission as problems of research.

At the same time, statistical approaches became increasingly important. Their approach was oriented toward the distribution of variation among individuals rather than continuity or differences among species. This work laid the foundations of modern multivariate statistics. ${ }^{11}$ In 1909 Wilhelm Johannsen extended these ideas by distinguishing between variation among individuals and variation among "lines." This notion was elaborated further by J. A. Harris, R. A. Fisher, and Sewell Wright. In 1922 Fisher extended this line of thinking once again by removing the need to consider lineage explicitly. Instead, variation could be analyzed in a population without respect to genealogy. With this result, geneticists were no longer obliged to know or care how an individual fitted into a lineage. ${ }^{12}$ This work in population genetics enabled a re-conceptualization of evolution. The older view was that evolution was conversion of continuity into diversity via adaptation of parts. In the new view, evolution became the conversion of differences among instances of a single kind (individual organisms) into differences among multiple kinds (species). This is 
the conventional view of current biology. Synchronic populations rather than diachronic lineages became the chief category for thinking about what lay between individuals and species.

Fisher's statistical stroke of 1922 was paralleled by a simultaneous second one in evolutionary theory. In the view of evolutionary morphology, individual life-cycles were the product of a species' growth; the succession of generations gave rise to more individuals. In 1922 Walter Garstang turned this upside down by defining phylogeny as a sequence of lifecourses. ${ }^{13}$ The history of a clade thus became a simple aggregation of individual lives. There was no longer a casual connection between phylogeny and ontogeny. The work of Fisher and Garstang meant that evolution and development could be studied in virtually complete independence of one another.

\section{Evo-Devo: Sources of change in the late twentieth century}

The conventional history of biology has focused on the critical role of populational concepts in the development of modern evolutionary theory, and that is correct. It is a cliché that development was excluded from the Modern Synthesis. ${ }^{14}$ But the changes that gave rise to the Modern Synthesis were also a shift from concern with part-whole relations (centered on adaptation and morphology) to instance-kind relations (centered on sorting and segregating). This distinction is crucial.

Construing something in terms of part-whole or compositional relations means looking at its organization as a system of parts which work together. For example, my finger is part of my hand, which is part of my arm, which is part of my body. The focus is on the ways in which different parts are connected and interact. Comparisons of different arms (or forelimbs) is in the service of understanding differences in function.

By contrast, construing something in terms of instance-kind or aggregative relations means looking at it as an example of a class of things. Rather than see fingers, hands, and arms as connected things, this view sees them as objects with properties such as size, shape, color and so on. Comparison of different forelimbs is in the service of understanding differences in the variation of properties, and hence of differences among kinds.

Neither of these approaches is superior to the other; they are simply different (and complementary) ways of framing the objects of research. But these differences have profound 
implications. As the shift in frame occurred early in the twentieth century, nature metaphorically became, not Paley's craftsman making watches one at a time, but Chaplain's factory making things from interchangeable parts in huge batches. The Modern Synthesis entrenched and solidified this shift of concerns, and hence the division of research labor. In doing so, it was completing a process which had been underway for half a century.

In the last part of the twentieth century, the study of evolutionary and the study of development have rejoined enthusiastically. The result, commonly now called "Evo-Devo," has become one of the most vigorous parts of biology. ${ }^{15}$ Many of the larger problems which motivate research in the new area are clearly descended from (or are the same as) the problems which motivated researchers a century ago. Yet there are important differences as well. These are not simply a function of the more specialized knowledge and advanced techniques used by today's researchers. Rather, they stem from changes in the organization of research problems and specialties over a long period.

The most striking thing about Evo-Devo is that it consists of a system of effective alliances among just those lines of research that were excluded from the web of events which led to the Modern Synthesis. It was, after all, not just development which was excluded from the Modern Synthesis, but all the lines of work which did not easily follow the shift in stylistic emphasis from part-whole relations to instance-kind relations. These included morphology, problems of community structure in ecology, phylogeny, and even studies of gene function ("physiological genetics") not to mention behavior and comparative physiology. ${ }^{16}$ This progressive long-term exclusion is summarized diagrammatically in Figure 1.

\section{Insert Figure 1 here}

In the first generation after the Modern Synthesis, these areas of research were the weaklings of comparative biology in terms of available attention and resources. Their intersection and alliance in the last generation has become one of the most active and promising parts of comparative biology. This reversal of fortune came about because the institutional context of research changed in ways that opened possibilities which had been discouraged for a long time. The changes were complex, and the influences they had are more so. Here, I will focus on four kinds of recent change that have interacted to foster the 
intersection of evolutionary and developmental biology. These are: developments in research technology, the rationalization of work both in the larger society and in lines of research, changes in the prevalence of certain styles of research, and certain changes in the conceptual organization of evolutionary research. There were many other important factors, but these four allow us to see the outlines of the story most clearly.

\section{Developments in research technology}

I said above that natural history ran into serious technical difficulties at the end of the nineteenth century. These problems made it difficult to follow a program of comparative research that retained the close ties between development and evolutionary biology. The last part of the twentieth century, in contrast, was quite striking for its development of many techniques and procedures which provide fresh traction on the traditional problems of comparative biology in general, and on the problems of Evo-Devo research in particular. These new techniques and procedures have dramatically sharpened the questions that comparative biologists can ask effectively. The most important of these research technologies can be summed up in three broad, mutually supportive and overlapping groups: molecular technology, computing technology, and visualization technology.

By molecular technology, I mean the techniques of molecular biology applied to problems of Evo-Devo research. The development of molecular biology was one of the outstanding success stories of twentieth-century science. ${ }^{17}$ The primary significance of this work for Evo-Devo does not lie in the development of molecular explanations of transmission or even gene function, for all that these are extremely important. Rather, the significance of molecular biology is that it provides a family of tools and techniques for observing and manipulating the earliest stages of development, and hence, the most profound aspects of morphology. ${ }^{18}$

The study of developmental genetics in turn provides the basis for important ties with evolutionary theory. ${ }^{19}$ Here, the study of gene expression and function merge imperceptibly into the study of development proper. The associations among the early, the old, the small, and the profound holds as much interest now as it did a century ago, for all the interpretive context is very different. Evo-Devo researchers can, by these using the 
molecular techniques, fruitfully concern themselves with questions which were impossibly difficult only recently.

Computing technology has come to play an important role in all parts of research. Molecular genetics, in particular, has made extensive use of computational or informationtheoretic metaphors, ${ }^{20}$ but these uses are not my concern here. Instead, I am concerned with the use of computing (whether as hardware, software, or both) as a part of the procedures used to conduct research. This includes collecting, processing, visualizing, storing, organizing and analyzing data; modeling and simulating biological processes; and communicating the results of these efforts. These uses of computing now pervade every aspect of the research process. Since there are so many applications, it is difficult to single out any one of them as being especially significant. The important result of large-scale computing use is that the effective power of comparative approaches has been vastly extended, and this is turn means that many of the problems which could not be addressed effectively at the end of the nineteenth century were being addressed at the end of the twentieth.

Consider the development of computer-based museum specimen catalogs as an example. ${ }^{21}$ In recent years there has been a concerted effort by the world's museums to automate their specimen catalogs and make them available to scholars over the Internet. This seems a mundane and obvious administrative chore, but its implications reach quite far. Information storage and retrieval technology is crucial to comparative research. A century ago, index cards and standardized note-taking procedures were the high-tech cutting edge of museum practice, as they were in industry. ${ }^{22}$ The development of specimen databases is a straightforward extension of traditional practice. It is significant because collection databases and the Internet enable a vast increase in the amount of comparative work that can be done, a substantial increase in the thoroughness of its coverage, and a dramatic drop in the costs of doing it. In this context, it is important to keep in mind that a significant number of discoveries are made in the course of re-examining specimens already in museum collections.

Another example is provided by the debates over classification methods in the last generation. ${ }^{23}$ One important consequence of these debates has been a marked increase in the rigor of phylogeny and classification studies. This increase would have been far more difficult to establish as a practical part of research without computing technology to deal with the data analysis requirements. 
Visualization techniques have also played an important role in advancing Evo-Devo. Procedures for representing evolutionary and developmental processes have always been important. ${ }^{24}$ In recent years, the number and variety of techniques available has grown rapidly. Many, but not all, of these new techniques are computer-based; almost all are computer-aided.

Improvements in microscopy, for example, have made a substantial difference to almost all lines of biological research. A century ago, light microscopy had reached its effective limits. The development of electron microscopy at the time of World War II opened up many new possibilities. ${ }^{25}$ Since then, several new forms of microscopy have been developed. The most important of these for the biological research purposes is scanning electron microscopy, which enables detailed morphological study across several levels of scale which were unreachable before.

X-ray technology has also proven an important tool for visualization. ${ }^{26}$ One particularly interesting application of this technology is the use of $\mathrm{x}$-ray tomography (CAT scanning) to construct computerized pictures of skeletal elements. Rowe, for example, used an industrial CAT scanner to map the skull of an ancient Didelphid. The resulting data base allows the structure of the skull to be displayed on a computer monitor. The image can be manipulated in many ways, so that the most detailed analysis in three dimensions is possible without destroying the specimen. And of course, multiple scans can be juxtaposed and compared, either visually on screen or as data sets for computerized analysis. ${ }^{27}$ Building on this work, Rowe has led the development of a substantial research facility devoted to CAT scanning, and available to the scientific community. ${ }^{28}$

Many other examples are possible, but the point is clear: an abundance of new technologies for working with and comparing specimens means that many of the classical nineteenth century problems of evolutionary biology, intimately connected to developmental questions, can be fruitfully addressed once again.

\section{Rationalization of work}

In the first two-thirds of the twentieth century there was widespread emphasis on rationalization- doing more with the same resources, or the same with fewer resources. Across many institutions, concern focused on making activities more efficient and lower in unit cost. This is turn meant an emphasis on homogeneous raw materials and an elaborate 
division of labor designed to ensure high volumes of production. In particular, rationalization meant eliminating contingencies and connections among things wherever possible, and emphasizing homogeneity, removal of properties held to be irrelevant, independence of parts, and simplicity of relations.

A critical nineteenth century innovation in this respect was the invention of the “American System" of manufacture. ${ }^{29}$ Craft-oriented production, like Paley's watch-maker, focused on the hand-fitting of variable parts. By contrast, in the American System, all parts of a given type are made to such close tolerances, that any one of a type can substitute for any other in the production process. This meant that parts could be treated as if they were equivalent instances of a kind, assured of their correct articulation with other parts of different types. This in turn enabled much lower labor costs, since objects could be assembled by cheaper workers with less skill, who didn't have to hand fit variable parts together. It also enabled a more fine-grained division of labor and higher volumes of production. In the early twentieth century, this approach was extended from the manufacture of objects to the manufacturing process itself. Each step became a matter of repeating simple standardized actions in exactly the same way. The classic expression of this approach is the work of F. W. Taylor. ${ }^{30}$

The organization of research, as with every other industry, was rationalized in the twentieth century. The industrialization of academic research went furthest and fastest in the US, but it also took place in other industrializing countries. One way in which the rationalization process affected research was to encourage the segmentation of research specialties, which increasingly focused on narrower and narrower problems. Rationalizing research lines were particularly concerned to eliminate ("black box") problems of adaptation, complexity, interaction, and dependence. The development of statistical theory, intimately involved with problems of genetics and evolution, treated organisms as abstract data points with few properties. ${ }^{31}$

Some lines of research fell in with this way of doing things very easily — notably genetics, especially population genetics. Others found it very difficult to do so, because the structure of their problems (and hence, their intellectual coherence as lines of work) made it very difficult to shift. Research in behavior as an evolutionary phenomenon, for example, suffered greatly because behavior was conceptualized as an adaptive mechanism, "fitting" individual organisms and species to their environments. ${ }^{32}$ Research on community structure suffered for the same reason, and ecology failed to thrive until it was reconceptualized as 
concerned with statistical distributions of species. ${ }^{33}$ Research on morphology and on development, inseparable from the question of parts and their relationships in space and time, was almost completely separated from work on evolution.

More generally, work on multi-faceted problems was discouraged by this pattern of specialization. Since evolution and development were each themselves complex multi-sided problems, their intersection was especially problematic. Indeed, there was a clear two-part pattern to the development of new specialties in biology. First, some specialties (e.g., genetics) concentrated on problems and approaches which could be rationalized relatively easily, while other specialties (notably, development) focused on problems approaches which were difficult to rationalize. Second, the specialties with difficult-to-rationalize problems were less successful in creating new breakthroughs, and attracting funds and attention. But they rationalized nonetheless, if more slowly and painfully, as did the organizations which housed and financed them.

The Modern Synthesis at mid-century then, was an alliance among specialties which had easily rationalizable problems (or, more precisely, whose problems seemed easily rationalizable at the time). These included population genetics and cytogenetics, a systematics re-defined to focus on counting characters, and a paleontology focused on a statistical and analytic treatment of clades, not description of taxa. ${ }^{34}$ The most difficult problems of evolutionary theory (e.g., speciation, the nature and role of adaptation) were treated by replacing interaction among parts and among organisms with simple quantitative differences in reproductive success. This is analogous to using sales volume as a measure of engineering quality.

\section{Stylistic change}

Every approach to research requires scientists to make many specific commitments about the ways they allocate resources. Each hypothesis, for example, implies certain kinds of data collection and analysis, and each technique requires certain materials and tools. The decisions to work in one way rather than another in turn are guided by styles of research. Styles are abstract commitments used to organize other, relatively concrete, commitments. ${ }^{35}$ Styles typically appear as general philosophical or methodological positions; e.g., focusing on 
structural rather than functional considerations, or preferring the construction of formal models to the detailed description and analysis of particular cases. ${ }^{36}$ Any such pattern of commitments can serve to frame a line of research problems. Stylistic conflicts within a line of research are routine.

One important dimension of style was the commitment to partitioning vs. integrative approaches. Some kinds of research focus on dividing the phenomena into its constituent parts or instances, in order to understand things in terms of their constituents and the relationships among them. This is the partitioning style. In contrast, the integrative style concentrates on setting phenomena in context, understanding them in terms of their relations with the world around them. In order to find out why a chicken crosses the road, a partitioning scientist might undertake neurosurgery, while an integrative scientist might design experiments with different roads, different chickens, and different traffic conditions.

The rationalization process so characteristic of twentieth-century science (and other institutions) was pre-eminently characterized by the partitioning style. By the middle of the twentieth century, it was becoming clear that certain classes of problem were not responding to these rationalizing styles of work organization. These problems are those that are irredeemably concerned with relations among elements, interaction among parts and processes. In the manufacturing industries, these issues showed up as problems of optimization, resource allocation, and coordination. These problems appeared almost everywhere, even in accounting ${ }^{37}$ Several managerial and engineering disciplines emerged to deal with these problems in the middle years of the century, typically under the rubric of "systems." 38

The same emphasis on systems and issues of coordination which characterized other institutions appeared in biology research as well - especially in development and ecology. But here an interesting contrast appeared. In many uses of the systems approach, the language of systems was a way of extending the rationalizing trend in the partitioning style. The problem was to overcome the intricacies imposed by contingency and complex dependencies through the use of more sophisticated analysis. This view was especially strong in the emergent sister disciplines of operations research and industrial engineering. It was brought into biology by Robert MacArthur, who applied these approaches, learned in his wartime work, to ecological problems under the influence of G.E. Hutchinson. ${ }^{39}$ 
In contrast, other biologists, notably von Bertalanffy and Waddington, saw the systems approach as a way of transcending the limits of the partitioning approach. ${ }^{40}$ For them (and they were notably students of development and morphology), the systems approach was a way to conceptualize and deal with the complex interrelations of system and environment. Here, the focus was on ways of representing the effects of context. Adherents of these two ways of thinking about systems often talked past one another, but rarely got into explicit debates over the meaning of "system"; rather, they were invariably focused on overcoming the limitations of the partitioning approach, either by reforming it or by substituting some kind of integrative view. By the 1970s, it was clear that systems approaches were not, in general, very effective ways of organizing work either in research or in other institutions. Some applications of industrial engineering ideas in the 1960s failed loudly enough to bring the entire systems approach into question. ${ }^{41}$

Progress in molecular genetics was showing that simple partitioning strategies were not going to provide adequate explanations of gene expression. ${ }^{42} \mathrm{~A}$ variety of critics of the Modern Synthesis raised objections to it from a more interpretive perspective. ${ }^{43}$ In many areas of biological research touching on evolutionary problems, scientists were beginning to reformulate their work in terms more sympathetic to integrative approaches. ${ }^{44}$ Increasing openness to integrative approaches facilitated the emergence of an explicit Evo-Devo intersection in the late 1970s and early 1980s.

Another important stylistic shift in the late twentieth century was the re-opening of concern with parts and wholes, in contrast to instances and kinds. The Modern Synthesis was firmly rooted in the instance-kind approach. The approach of population genetics and the widespread adoption the populational approach to systematics and paleontology firmly entrenched the idea that species were sets of instances. Indeed, some trends in evolutionary research in the 1960s and 1970s seemed to build upon this approach and entrench it further. Williams' attack on group selection, for example, emphasized the instance/kind approach. The emergence of sociobiology in the 1960s extended the approach to the analysis of behavior as well. ${ }^{45}$

But efforts to work in the instance/kind style were also running into difficulties by the 1960s. There were questions about the adequacy of the approach, even as the central alliance of the Synthesis was showing strain. ${ }^{46}$ Questions about adaptation were reappearing in morphology. ${ }^{47}$ There was increased concern with symbiosis, the problem area least 
amenable to an instance/kind approach. ${ }^{48}$ Developmental biology had never given up its part/whole orientation to problems of morphogenesis. A major review of the field published in 1955 shows a thorough-going commitment to construing the developmental process as one of part-whole relations. ${ }^{49}$ Doubts about the adequacy of the instance/kind style appeared even in population genetics, the heartland of the approach. ${ }^{50}$ In short, the instance/kind style proved inadequate to deal with problems involving adaptation, communication, coordination, articulation, and cooperation. At the same time, these problems were becoming of increasing interest and importance. As evolutionary research in the 1960s and 1970s began to consider approaches that did not rely on commitment to the instance/kind style, the possibility of a stylistic rapprochement between evolutionary and developmental approaches emerged.

\section{Conceptual change}

The concepts scientists use to organize their work change all the time. Some of these changes are important, but are not closely connected to the basic issues of the field. From an evolutionist's point of view for example, the many striking changes in the concept of "gene" that took place over the twentieth century do not make for substantive differences in the ways that species and speciation are conceptualized. Other conceptual changes, by contrast, enable important shifts in the way lines of research interact, formulate their projects, and interpret their results.

The beginnings of a rapprochement between development and evolution researchers in the late 1970s was facilitated by conceptual changes which reduced the distance between the two lines of work. Two of the more important conceptual shifts in this period were the idea of species as individuals, and the notion of heterochrony.

The Modern Synthesis saw individual organisms as members of populations. It thus conceptualized the relationship of individuals to their species as one of instances and kinds. In 1974, Ghiselin suggested that species are individuals rather than kinds. ${ }^{51}$ Rather than independent instances of an abstract class, Ghiselin saw species as concrete individuals, characterized by historical existence (i.e., a birth and death) and relationships among 
members which provided coherence to the whole. In particular, species are made up of breeding relationships among member organisms, and hence of lineages. In this view, the relationship of a particular organism to its species is one of part to whole, rather than one of instance to kind. The idea was endorsed by the philosopher David Hull in $1976 .^{52}$

This idea provided an important conceptual basis for a rapprochement between researchers committed to different approaches in evolution and development research. ${ }^{53}$ It is far easier to think about integrated approaches to evolution and development if one does not have to reconcile two incompatible ways of thinking. This increase in conceptual homogeneity makes it easier to formulate relatively specific research problems. Viewing species as individuals thus was an important, if unobvious, facilitating step which made the connection between evolutionary and developmental biology easier as the idea gained broad acceptance.

The Modern Synthesis in Britain was not quite so thoroughgoing in its rationalization of problems and concepts as it was in the United States. There was some room for consideration of development in the British Synthesis; morphologist Gavin de Beer published studies of some issues in the comparative study of development. ${ }^{54}$ De Beer was extending the work of Garstang on the relationship between development and evolution. ${ }^{55}$ Accepting Garstang's idea of evolution as a sequence of life-cycles, de Beer re-framed many of the questions which had concerned Haeckel and his followers. In particular, he concentrated on heterochrony, the idea that some species retained or lost characters associated with particular phases of the life cycle. This work fell on stony ground; for a generation after World War II, it was little more than a sideline which generated little new research.

In 1977, Gould published a major study of heterochrony which did much to revive concern with relationship between evolution and development. ${ }^{56}$ Gould was concerned to make the notion of heterochrony respectable, and in order to do this he had to remove the stigma of Haekelian recapitulation from it. He did this by systematically reviewing the history of the recapitulation idea and its vicissitudes, taking great care to show that the modern notion of heterochrony was quite compatible with "Darwinian" (i.e., Modern Synthesis) thought.

Gould also modified the idea of heterochrony in important ways. For de Beer, heterochrony was (paradoxically) a static notion: he saw different kinds of character pattern, 
with "early" and "late" features of development appearing in different (but presumably related) species. This view is structural, not processual. Gould's innovation was to think of heterochrony as a matter of different rates of development among different parts of the body across different species. Some of the organs of some species, that is, aged faster (or slower) than others, or halted their development sooner or later in the life-cycle.

This way of looking at heterochrony was important because it cuts in two different directions. On the one hand, it naturally provokes questions about the mechanisms that control differential rates of growth in morphogenesis, and this naturally leads on to questions about the genetic control of growth. On the other hand, this view leads to questions about relatively large morphological differences among clades, and to thoughts of evolutionary innovation and radiation. These are questions of great interest to paleontologists and others interested in large scale evolution. ${ }^{57}$ Heterochrony is thus a "bridge" concept which spans the distinctions among size or scale of phenomena which became an important part of evolutionary biology after the Modern Synthesis.

The study of heterochrony has developed into an important part of Evo-Devo. ${ }^{58}$ More generally, it provides a conceptual framework in which paleontologists, developmental biologists and morphologists can talk about parts and their relations at a large (i.e., early, old, profound) scale, just like they used to do before World War I. And it does so, moreover, in a way which does not necessarily bring contumely from geneticists and systematists.

\section{Conclusions}

All these technical and conceptual changes have placed the relationship between evolutionary and developmental biology on a new basis. Rather than two separate worlds, the two lines of research have now become a major cluster of intersections in which many problems and research efforts are simultaneously part of both evolutionary and developmental biology.

The changes in the intellectual content of research during the twentieth century were tied to, and reflected, corresponding changes in the larger society. The pattern of influence is complex, but the main outline is clear. For the first two-thirds of the twentieth century, rationalization was a driving force across institutions and levels of organizational scale. Lines of research which could be easily rationalized had a considerable advantage in the quest for every kind of financial and organizational support. At one level, organizations which adopted 
"business-like" administrative procedures could more easily attract funds and public support ${ }^{59}$ At another level, research programs whose projects were of a size and cost convenient for the efficient production of $\mathrm{PhDs}$ and undergraduate laboratory classes (e.g., fruit-fly genetics) were at a comparative advantage by comparison with programs that were administratively inconvenient (e.g., biogeography).

There were many other contingencies, but at every point, some programs were better off, better able to compete, than others. Some programs (such as Mendelian genetics based on breeding experiments) enjoyed this relative advantage quite often, and these flourished. Others (such as community ecology) struggled. Overwhelmingly, the relatively successful projects were those which fit comfortably into a rationalizing world.

The same relative advantages occurred with stylistic commitments as well. Some styles were commensurate with the prevailing trend toward rationalization (e.g., partitioning, instance-kind) and others aren't (interpretive, part-whole). Approaches which adopted the commensurable styles had advantages over those which did not, and were thus relatively successful

There were exceptions to the trend, in research as in other parts of the institutional structure. ${ }^{60}$ Some lines of research (notably, vertebrate paleontology) were able to establish supporting alliances outside the rationalizing system of alliances among disciplines, sponsors, and universities. But in general, programs stylistically, intellectually, and organizationally amenable to rationalization enjoyed a steady incremental accumulation of advantage.

This process reached its peak with the late Modern Synthesis. In the late 1960s, the limits of the rationalizing approach had been reached, and attention started to turn once again to problems which had been by-passed in the previous generation. By the end of the 1970s, there was a clear counter-trend under way, in the larger society as well as in biology. This emphasized coordination, adaptation, the articulation of parts, and holism. In this context, the intersection of evolutionary and developmental biology in the late 1970s was a natural step in a world that was quite ready for it. The cumulative advantages that flowed to rationalizing work in the first part of the century began flowing instead to efforts that emphasized interdisciplinary collaborations and a fascination with levels, networks, and complexity.

Evo-Devo has now built up substantial institutional and intellectual momentum. There are journals, conferences, and all of the institutional apparatus of a flourishing line of research. Where is the juncture going? Will it be successful? Will there be a coherent 
discipline of Evo-Devo? Is a new and more general theory emerging? I don't know. Biologists will organize and settle their research problems well enough, and they have little to gain from the kibitzing of an ill-trained amateur such as myself. My concern as a sociologist is not with the answers scientists come up with, but with understanding how and why they come up with them, the ways in which they work, and the arrangements which facilitate and constrain that work.

But I can't help but note that the successful development of Evo-Devo does not depend on the emergence of a single successful perspective or theory which will then guide research. We often have disciplines without such coherent perspectives; indeed, I think they are the typical case. Rather than common answers, the field will be defined by joint (and competitive) attack on common problems. And if it's anything like all the other disciplines, there will be many debates and differences in viewpoint. This is ordinary metabolism, not pathology. 
${ }^{1}$ 1980, see especially Hamburger 1980.

${ }^{2}$ Mayr 1991, Sapp 1987, 2003.

${ }^{3}$ Gerson 1998.

${ }^{4}$ Muller 1862, Haeckel 1866. See Russell 1916, Nyhart 1995.

${ }^{5}$ Bowler 1989, 1996, Gee 1996.

${ }^{6}$ Bowler 1996, Gee 1996, Nyhart 2002.

${ }^{7}$ Coleman, 1970.

${ }^{8}$ Churchill 1973, Gould 1977.

${ }^{9}$ Churchill 1987, Winter 2001.

${ }^{10}$ Griesemer and Wimsatt 1989, Maienschein 1991, Allen 1985.

${ }^{11}$ MacKenzie 1981, Kim 1994, Porter 1986, Gigrenzer et al. 1989.

${ }^{12}$ Johannsen 1909, 1911; Harris 1911a,b, R. A. Fisher 1918, Sewell Wright 1918; Fisher 1922. Provine 1986 is the best single account.

${ }^{13}$ Garstang 1922.

${ }^{14}$ For populational concepts, cf. e.g., Mayr 1982, Provine 1986.. For the exclusion of development, cf. Churchill 1980, Hamburger 1980.

${ }^{15}$ Some major works and recent collections of the intersection include, for example: Akam et al. 1994, Arthur 1997, Bonner 1983, Goodwin et al. 1983, Gould 1977, Hall 1992, Hall and Wake 1999, Jackson et al. 2001, Møller, and Swaddle 1997, Raff 1996, and Raff and Thomas 1983, 2 ed. 1991, Wagner 2001, in press, West-Eberhard 2003.

${ }^{16}$ Ghiselin 1980, Bowler 1996, Goldschmidt 1938.

${ }^{17}$ Olby 1974, Judson, 1979, Kay 1993, 2000.

${ }^{18}$ This point is complemented by the theoretical and philosophical work of Riedl (1978) on "burden" and Wimsatt (e.g., 1986, 2001) on "generative entrenchment".

${ }^{19}$ For development genetics, see, e.g., Gehring 1998, For ties to evolutionary theory, see Raff and Kaufman 1983, 1991; Raff 1996, Schank and Wimsatt 1986

${ }^{20}$ Oyama 1985, Griesemer, In limbo.

${ }^{21}$ This example is based on unpublished work in collaboration with James R. Griesemer.

${ }^{22}$ Goode 1991, Grinnell 1910, Yates 1989. 
${ }^{23}$ Hull 1988.

${ }^{24}$ e.g., Hopwood 1999.

${ }^{25}$ Rasmussen 1997.

${ }^{26}$ Kevles, 1997.

${ }^{27}$ Rowe, 1996.

${ }^{28}$ The facility can be seen at http://www.ctlab.geo.utexas.edu/. The associated digital morphology library at http://www.digimorph.org provides impressive examples of the technical trends discussed here.

${ }^{29}$ Smith 1977, Hounshell 1984, Hoke 1990.

${ }^{30}$ F. W. Taylor 1911.

${ }^{31}$ Gigarenzer et al. 1989.

${ }^{32}$ Research which treated behavior as instance-kind relations flourished in the neighboring discipline of psychology (O'Donnell 1985, Acree 1978).

${ }^{33}$ McIntosh, 1975, Hagan 1992, Kohler 2002.

${ }^{34}$ For paleontology, see Cain 1990, Laporte 2000.

${ }^{35}$ Gerson 1998.

${ }^{36}$ Harwood's analysis (1993) of styles of research coincides well with my view.

${ }^{37}$ e.g., Johnson and Kaplan 1987

${ }^{38}$ Heims 1991, Hughes and Hughes 2000, Hammond 2003.

${ }^{39}$ Cody and Diamond 1975.

${ }^{40}$ von Bertalanffy 1933, 1952; Waddington 1940, 1967-72.

${ }^{41}$ Hoos 1972, Berlinski 1976.

42 e.g., Stent 1981

${ }^{43}$ See especially Gould and Lewontin 1979; but also, e.g., Ho and Saunders 1984, Goodwin and Saunders 1992.

${ }^{44}$ e.g., Alberch et al. 1979, Gould 1977, Levins 1966, Lewontin 1974.

${ }^{45}$ Williams 1962, Hamilton 1996.

${ }^{46}$ Grene 1958, 1961, Rudwick 1964; Mayr 1959.

${ }^{47}$ e.g. Bock and von Wahlert 1965, Love 2003, this volume.

${ }^{48}$ Sagan 1967. 
${ }^{49}$ Willier et al. 1965.

${ }^{50}$ Lewontin 1974.

${ }^{51}$ Ghiselin 1974.

${ }^{52}$ Hull 1976.

53 e.g., Gould 2002.

${ }^{54}$ de Beer 1930, 1940a, 1940b.

${ }^{55}$ Garstang 1922.

${ }^{56}$ Gould 1977.

${ }^{57}$ e.g., Alberch et al. 1979

${ }^{58}$ McKinney 1998, McKinney and McNamara 1991, McNamara 1997, Zelditch 2001

59 cf. e.g., Barrow, 1990

${ }^{60}$ Berk 1994, Scranton 1997, Shenhav 1999 and Perrow 2002 discuss the exceptions to the trend in the manufacturing sector. 


\section{REFERENCES}

Abbott, Andrew. 1995. “Things of boundaries." Social Research 62: 857-882.

Acree, Michael. C. 1978. Theories of Statistical Inference in Psychological Research: A HistoricoCritical Study. Unpublished Psychology Dissertation. Worcester, MA: Clark University.

Akam, Michael, et al. 1994. (Eds.) The Evolution of Developmental Mechanisms. Cambridge: Company of Biologists.

Alberch, Per, Stephen J. Gould, George F. Oster and David B. Wake. 1979. "Size and shape in ontogeny and phylogeny." Paleobiology 5: 296-317.

Allen, Garland. 1986. "T. H. Morgan and the split between embryology and genetics, 1910 - 1935." Pp. 113-146 in T. J. Horder, J. A. Witkowski and C. C. Wylie (Eds.) A History of Embryology. Cambridge: Cambridge University Press.

Amundson, Ronald. 1994. "Two concepts of constraint: Adaptationism and the challenge from developmental biology." Philosophy of Science 61: 556-578.

Amundson, Ronald. 2001. "Adaptation and development: On the lack of common ground." Pp. 303-334 in S. H. Orzack and E. Sober (Eds.) Adaptationism and Optimality. New York: Cambridge University Press.

Arthur, Wallace. 1997. The Origin of Animal Body Plans: A Study in Evolutionary Developmental Biology. New York: Cambridge University Press.

Arthur, Wallace. 2000. "Intraspecific variation in developmental characters: The origin of evolutionary novelties." American Zoologist 40: 811-818.

Baldwin, James M. 1902. Development and Evolution. New York: Macmillan.

Barrow, Clyde. W. 1990. Universities and the Capitalist State: Corporate Liberalism and the Reconstruction of American Higher Education, 1894 - 1928. Madison, WI: University of Wisconsin Press.

Becker, Howard S. 1960. "Notes on the concept of commitment." American Journal of Sociology 66: 32-40.

Becker, Howard S. 1982. Art Worlds. Berkeley: University of California Press.

Berk, Gerald. 1994. Alternative Tracks: The Constitution of American Industrial Order, 1865 1917. Baltimore: Johns Hopkins University Press.

Berlinski, David. 1976. On systems analysis: an essay concerning the limitations of some mathematical methods in the social, political, and biological sciences. Cambridge, MA.: MIT Press.

Bock, Walter. J. and G. vonWahl ert. 1965. "Adaptation and the form-function complex." Evolution 19: 269-299.

Bowler, Peter J. 1983. The Eclipse of Darwinism: Anti-Darwinian Evolution Theories in the Decades around 1900. Baltimore: Johns Hopkins University Press.

Bowler, Peter J. 1989. "Development and adaptation: Evolutionary concepts in British morphology, 1870 - 1914." British Journal of the History of Science 22: 283 - 297.

Bowler, Peter J. 1996. Life's Splendid Drama: Evolutionary Biology and the Reconstruction of Life's Ancestry, 1860 - 1940. Chicago: University of Chicago Press.

Bonner, John T. (Ed.) 1983. Evolution and Development. Berlin: Springer-Verlag.

Cain, Joseph A. 1990. "George Gaylord Simpson's 'History of the Section of Vertebrate Paleontology in the Paleontological Society'." Journal of Vertebrate Paleontology 10: 40-48.

Cartwright, Nancy. 1983. How the Laws of Physics Lie. New York: Oxford University Press.

Cartwright, Nancy. 1989. Nature's Capacities and Their Measurement. New York: Oxford University Press. 
Chandler, Alfred D. 1990. Scale and Scope: The Dynamics of Industrial Capitalism. Cambridge, MA: Harvard University Press.

Churchill, Frederick B. 1973. "Chabry, Roux, and the experimental method in 19th century embryology." Pp. 161-205 in Ronald N. Giere and Robert S. Westfall (Eds.) Foundations of Scientific Method: The Nineteenth Century. Bloomington, IN: Indiana University Press.

Churchill, Frederick B. 1980. "The modern evolutionary synthesis and the biogenetic law." Pp. 112-122 in E. Mayr and William B. Provine (Eds.) The Evolutionary Synthesis. Cambridge, MA: Harvard University Press.

Churchill, Frederick B. 1987. "From heredity theory to Vererbung: The transmission problem, 1850 - 1915." Isis 78: 337 - 364.

Clements, Frederick. 1907. Plant Physiology and Ecology. New York: Holt.

Cody, Martin L. and J.M. Diamond. 1975. "Introduction.” Pp. $1-12$ in Martin L. Cody and Jared L. Diamond (eds.) Ecology and Evolution of Communities. Cambridge, MA: Harvard University Press.

De Beer, Gavin R. 1930. Embryology and Evolution. Oxford: Oxford University Press.

De Beer, Gavin R. 1940a. "Embryology and taxonomy." Pp. 365-394 in Julian S. Huxley (Ed.) The New Systematics. Oxford: Oxford University Press.

DeBeer, Gavin R. 1940b. Embryos and Ancestors. Oxford: Oxford University Press.

Fisher, Ronald A. 1918. "The correlations between relatives on the supposition of Mendelian inheritance." Transactions of the Royal Society of Edinburgh 52: 399 - 433.

Fisher, Ronald A. 1922. "On the dominance ratio." Proceedings of the Royal Society of Edinburgh 42: 321 - 341.

Galison, Peter. 1997. Image and Logic: A Material Culture of Microphysics. Chicago: University of Chicago Press.

Garstang, Walter. 1922. "The theory of recapitulation: A critical re-statement of the Biogenetic Law." Zoological Journal of the Linnaean Society 35: 81-101.

Gaskins, Richard H. 1992. Burdens of Proof in Modern Discourse. New Haven: Yale University Press.

Gee, Henry. 1996. Before the Backbone: Views on the Origin of the Vertebrates. London: Chapman and Hall.

Gerson, Elihu. M. 1998. The American System of Research: Evolutionary Biology, 1890 - 1950. Unpublished Dissertation. Chicago: University of Chicago Department of Sociology.

Ghiselin, Michael T. 1974. "A radical solution to the species problem." Systematic Zoology 23: 536-544.

Ghiselin, Michael T. 1980. "The failure of morphology to assimilate Darwinism." Pp. 180-192 in E. Mayr and William B. Provine (Eds.) The Evolutionary Synthesis: Perspectives on the Unification of Biology. Cambridge, MA: Harvard University Press.

Gigerenzer, Gerd., et al. 1989. The Empire of Chance: How Probability Changed Science and Everyday Life. New York: Cambridge University Press.

Gilbert, Scott F. 1978. "The embryological origins of the gene theory." Journal of the History of Biology 11: 307-351.

Gilbert, Scott F. 1988. "Cellular politics: Goldschmidt, Just, Waddington and the attempt to reconcile embryology and genetics, 1938 - 1940." in R. Rainger, Keith R. Benson and J. Maienschein (Eds.) The American Development of Biology. Philadelphia: University of Pennsylvania Press.

Gilbert, Scott. F. 2000. "Genes classical and genes developmental: The different uses of genes in evolutionasry syntheses." Pp. 159-177 in P. Beurton, R. Falk and H.-J. 
Rheinberger (Eds.) The Concept of the Gene in Development and Evolution: Historical and Epistemological Perspectives. New York: Cambridge University Press.

Gilbert, Scott F. 2001. Developmental Biology. 6 ed. Sunderland, MA: Sinauer Associates.

Grinnell, Joseph. 1910. "The uses and methods of a research museum"." Popular Science Monthly 77: 163-169.

Goldschmidt, Richard B. 1938. Physiological Genetics. New York: McGraw-Hill.

Goode, George B. 1991. The Origins of Natural Science in America: The Essays of George Brown Goode. Sally G. Kohlstedt (Ed.) Washington, DC: Smithsonian Institution.

Goodwin, Brian. C., N. Holder and C. C. Wylie. (Eds.) 1983. Development and Evolution. Cambridge: Cambridge University Press.

Goodwin, Brian C. and Peter T. Saunders. 1992. Theoretical Biology: Epigenetic and Evolutionary Order From Complex Systems. Baltimore: Johns Hopkins University Press.

Gould, Stephen J. 1977. Ontogeny and Phylogeny. Cambridge: Harvard University Press.

Gould, Stephen J. 2002. The Structure of Evolutionary Theory. Cambridge, Mass.: Harvard University Press.

Gould, Stephen J., and Richard C. Lewontin. 1979. The spandrels of San Marco and the Panglossian paradigm: a critique of the adaptationist program. Proceedings of the Royal Society Ser. B 205:581-598.

Grene, Marjorie. 1958. "Two evolutionary theories." British Journal for the Philosophy of Science 9: 110 - 127; 185 - 193.

Grene, Marjorie. 1961. "Statistics and selection." British Journal for the Philosophy of Science 12: 25 - 42. Reprinted in 1974 as Pp. 154 - 171 of The Understanding of Nature. Boston: D. Reidel.

Griesemer, James R. In limbo. "The Informational Gene and the Substantial Body: On the Generalization of Evolutionary Theory by Abstraction."

Griesemer, James R. and William C. Wimsatt. 1989. "Picturing Weismannism: A case study of conceptual evolution." Pp. 75-137 in M. Ruse (Ed.) What The Philosophy of Biology Is: Essays for David Hull. Boston: Kluwer.

Haeckel, Ernst. 1866. Generelle Morphologie.

Hagen, Joel B. 1992. An Entangled Bank: The Origins of Ecosystem Ecology. New Brunswick, NJ: Rutgers University Press.

Hall, Brian K. 1992. Evolutionary Developmental Biology. London: Chapman and Hall.

Hall, Brian K. and M. H. Wake. (Eds.) 1999. The origin and evolution of larval forms. San Diego: Academic Press.

Hamburger, Viktor. 1980. "Embryology and the Modern Synthesis in evolutionary theory." Pp. 97-112 in Ernst Mayr and William B. Provine (Eds.) The Evolutionary Synthesis: Perspectives on the Unification of Biology. Cambridge, MA: Harvard University Press.

Hamilton, William D. 1996. Narrow Roads of Gene Land: The Collected Papers of WD Hamilton. Vol 1. Evolution of Social Behavior. New York: W.H. Freeman.

Hammond, Debora. R. 2003. The Science of Synthesis: Exploring the Social Implications of General Systems Theory. Boulder, CO: University Press of Colorado.

Harris, J. Arthur. 1911a. "The biometric proof of the pure lines theory." American Naturalist 45: $346-364$.

Harris, J. Arthur. 1911b. “The distribution of pure line means.” American Naturalist 45: 686 $-700$.

Harwood, Jonathan. 1993. Styles of Scientific Thought: The German Genetics Community, 1900 - 1933. Chicago: University of Chicago Press.

Heims, Steve J. 1991. The Cybernetics Group. Cambridge, MA: MIT Press. 
Ho, Mae-Wan, and Peter T. Saunders. 1984. Beyond Neo-Darwinism: an Introduction to the New Evolutionary Paradigm. London: Academic Press.

Hoke, Donald. R. 1990. Ingenious Yankees: The Rise of the American System of Manufactures in the Private Sector. Columbia University Press.

Hoos, Ida. 1972. Systems Analysis and Public Policy: A Critique. Berkeley: University of California Press.

Hopwood, Nick. 1999. "'Giving body' to embryos: modeling, mechanism, and microtome in late nineteenth-century anatomy." Isis 90: 462-496.

Hounshell, David A. 1984. From the American System to Mass Production, 1900 - 1932: The Development of Manufacturing Technology in the United States. Baltimore: Johns Hopkins University Press.

Hughes, Agatha C. and Thomas P. Hughes. (Eds.) 2000. Systems, Experts, and Computers: The Systems Approach in Management and Engineering, World War II and After. Cambridge, Mass.: MIT Press.

Hull, David L. 1976. “Are species really individuals?” Systematic Zoology 25: 174-191.

Hull, David L. 1988. Science as a Process: An Evolutionary Account of the Social and Conceptual Development of Science. Chicago: University of Chicago Press.

Jackson, Jeremy B. C., Scottt Lidgard and Frank K. McKinney. 2001. (Eds.) Evolutionary patterns : growth, form, and tempo in the fossil record in honor of Allan Cheetham. Chicago, IL: University of Chicago Press.

Johannsen, Wilhelm. 1909. Elemente der Exacte Erblichleitslehre. Jena: Gustav Fischer.

Johnson, H. Thomas, and Robert S. Kaplan. 1987. Relevance Lost: The Rise and Fall of Management Accounting. Cambridge, MA: Harvard Business School Press.

Judson, Horace F. 1979. The Eighth Day of Creation. New York: Simon and Schuster.

Kay, Lily E. 1993. The Molecular Vision of Life: Caltech, the Rockefeller Foundation, and the Rise of the New Biology. New York: Oxford University Press.

Kay, Lily E. 2000. Who Wrote the Book of Life? A History of the Genetic Code. Stanford, CA: Stanford University Press.

Kevles, Bettyann H. 1997. Naked to the Bone: Medical Imaging in the Twentieth Century. Reading, MA: Addison-Wesley.

Kim, Kyung-Man. 1994. Explaining Scientific Consensus: The Case of Mendelian Genetics. New York: Guilford Press.

Kohler, Robert E. 2002. Landscapes and Labscapes: Exploring the Lab-Field Border in Biology. Chicago: University of Chicago Press.

Laporte, Léo. 2000. George Gaylord Simpson: Paleontologist and Evolutionist. New York: Columbia University Press.

Laubichler, Manfred D. 2000. "Homology in development and the development of the homology concept." American Zoologist 40: 777-788.

Love, Alan. C. 2003. "Evolutionary morphology, innovation, and the synthesis of evolutionary and developmental biology." Biology \& Philosophy 18: 309-345.

Love, Alan. C.. This volume.

Levins, Richard. 1966. "The strategy of model-building in population biology." American Scientist 54: 421-431.

Lewontin, Richard C. 1974. The Genetic Basis of Evolutionary Change. New York: Columbia University Press.

Maienschein, Jane. 1987b. "Heredity/development in the United States, circa 1900." History and Philosophy of the Life Sciences 9: 79 - 93.

Maienschein, Jane. 1991. Transforming Traditions in American Biology, 1880 - 1915. Baltimore: Johns Hopkins University Press. 
Mayr, Ernst. 1959. "Where are we?" Cold Spring Harbor Symposia in Quantitative Biology 24: $1-14$.

Mayr, Ernst. and William B. Provine. (Eds.) 1980. The Evolutionary Synthesis: Perspectives on the Unification of Biology. Cambridge, MA: Harvard University Press.

Mayr, Ernst. 1991. "An overview of current evolutionary biology." Pp. 1-14 in L. Warren and H. Koprowski (Eds.) New Perspectives on Evolution. New York: Wiley.

Mackenzie, Donald A. 1981. Statistics in Britain, 1865 - 1930: The Social Construction of Scientific Knowledge. Edinburgh: Edinburgh University Press.

McIntosh, Robert P. 1975. "H. A. Gleason- 'Individualistic ecologist' 1882 - 1975: His contribution to ecological theory." Bulletin of the Torrey Botanical Club 102: 253 273.

McKinney, Michael L. 1988. Heterochrony in Evolution: A Multidisciplinary Approach. New York: Plenum Press.

McKinney, Michael L. and Kenneth J. McNamara. 1991. Heterochrony: The Evolution of Ontogeny. New York: Plenum Press.

McNamara, Kenneth J. 1997. Shapes of Time: The Evolution of Growth and Development. Baltimore: Johns Hopkins University Press.

Møller, Anders P. and John P. Swaddle. 1997. Asymmetry, developmental stability, and evolution. Oxford ; New York: Oxford University Press.

Müller, Fritz. 1862. Für Darwin. Translated in 1869 as Facts and arguments for Darwin. London: John Murray.

Nyhart, Lynn K. 1995. Biology Takes Form: Animal Morphology and the German Universities, 1800 - 1900. Chicago: University of Chicago Press.

Nyhart, Lynn K. 2002. "Learning from history: Morphology's challenges in Germany ca. 1900." Journal of Morphology 253: 2-14.

O'Donnell, J. M. 1985. The Origins of Behaviorism: American Psychology, 1870 - 1920. New York: New York University Press.

Olby, Robert C. 1974. The Path to the Double Helix. Seattle: University of Washington Press.

Oyama, Susan. 1985. The Ontogeny of Information. New York: Cambridge University Press.

Perrow, Charles. 2002. Organizing America: Wealth, Power, and the Origins of Corporate Capitalism. Princeton, NJ: Princeton University Press.

Porter, Theodore M. 1986. The Rise of Statistical Thinking: 1820 - 1900. Princeton, NJ: Princeton University Press.

Raff, Rudolf A. 1996. The Shape Of Life : Genes, Development, and the Evolution of Animal Form. Chicago: University of Chicago Press.

Raff, Rudolf A. and Thomas C. Kaufman. 1983. Embryos, Genes, and Evolution: The Developmental Basis of Evolutionary Change. New York: Macmillan. Second edition 1991.

Raff, Rudolf A. and G. A. Wray. 1989. "Heterochrony: developmental mechanisms and evolutionary results." Journal of Evolutionary Biology 2: 409-434.

Rasmussen, Nicholas. 1997. Picture Control: The Electron Micrscope and the Transformation of Biology in America, 1940 - 1960. Stanford, CA: Stanford University Press.

Riedl, Rupert. 1978. Order in Living Organisms. New York: Wiley.

Rowe, Timothy. 1996. "Coevolution of the mammalian middle ear and neocortex." Science 273: 651-654.

Rudwick, Martin. J. S. 1964. "The inference of function from structure in fossils." British Journal for the Philosophy of Science 15: 24-40. 
Russell, Edward S. 1915. Form and Function: A Contribution to the History of Animal Morphology. London: John Murray.

Sagan, Lynn. 1967. "On the origin of mitosing cells." Journal of Theoretical Biology 14: 225275.

Sarkar, Sahotra. 1999. "From the Reaktionsnorm to the adaptive norm: The norm of reaction, 1909 - 1960." Biology \& Philosophy 14(235-252).

Sapp, Jan. 1987. Beyond the Gene: Cytoplasmic Inheritance and the Struggle for Authority in Genetics. New York: Oxford University Press.

Sapp, Jan. 2003. Genesis: The Evolution of Biology. New York: Oxford University Press.

Schank, Jeffrey C., and William C. Wimsatt. 1986. "Generative Entrenchment and Evolution." PSA86 2:33-60.

Scranton, Phillip. 1997. Endless Novelty: Specialty Production and American Industrialization, 1865 - 1925. Princeton, NJ: Princeton University Press.

Shenhav, Yehouda A. 1999. Manufacturing rationality : the engineering foundations of the managerial revolution.

Smith, Merritt R. 1977. Harper's Ferry Armory and the New Technology: The Challenge of Change. Ithaca, NY: Cornell University Press.

Stent, Gunther S. 1981, "Strengths and Weaknesses of the Genetic Approach to the Development of the Nervous System" Annual Review of Neuroscience 4: 163-194.

Strauss, Anselm L. 1978. "A social worlds perspective." Studies in Symbolic Interaction 1: 119-128.

Strauss, Anselm L. 1991. Creating Sociological Awareness. New Brunswick, NJ: Transaction Books.

Taylor, Frederick W. 1911. The Principles of Scientific Management. New York: Harper.

von Bertalanffy, Ludwig. 1933. Modern Theories of Development. Oxford: Oxford University Press.

von Bertalanffy, Ludwig. 1952. Problems of Life: An Evaluation of Modern Biological Thought. New York: Wiley.

Waddington, Conrad H. 1940. Organizers and Genes. Cambridge University Press.

Waddington, Conrad H. 1967 - 72. (Ed.) Towards a Theoretical Biology. 4 Vols. Edinburgh: Edinburgh University Press.

Wagner, Gunther P. 1996. "Homologues, natural kinds, and the evolution of modularity." American Zoologist 36: 36-43.

Wagner, Gunther P. (Ed.) The character concept in evolutionary biology. San Diego, Calif.: Academic Press.

Wagner, Gunther P., C.-h. Chiu, and Manfred Laubichler. 2000. “Developmental evolution as a mechanistic science: The inference from developmental mechanisms to evolutionary processes." American Zoologist 40: 819-831.

Walton, Douglas. 1996. Arguments From Ignorance. University Park, PA: Pennsylvania State University Press.

Wake, David B., et al. 1991. "Development and evolution- The emergence of a new field." Pp. 582-588 in Vol. 1 of Elizabeth C. Dudley (Ed.) The Unity of Evolutionary Biology: Proceedings of the Fourth International Congress of Systematic and Evolutionary Biology. Portland, OR: Dioscorides Press.

West-Eberhard, Mary J. 2003. Developmental plasticity and evolution. New York: Oxford University Press.

Williams, George C. 1962. Adaptation and Natural Selection. Princeton, NJ: Princeton University Press. 
Willier, Benjamin H., Paul A. Weiss and Viktor Hamburger. (Eds.) 1955. Analysis of Development. Philadelphia: W. B. Saunders.

Wimsatt, William C. 1974. "Complexity and organization." Pp. 67-86 in Kenneth F. Schaffner and R. S. Cohen (Eds.) PSA 1972. Dordrecht: D Reidel.

Wimsatt, William C. 1980. "Reductionist research strategies and their biases in the units of selection controversy." Pp. 213-259 in T. Nickles (Ed.) Scientific Discovery: Case Studies.

Wimsatt, William C. 1985. "Forms of aggregativity." Pp. 259-291 in A. Donagan, Anthony N. Perovich and Michael V. Wedin (Eds.) Human Nature and Natural Knowledge. Boston: Reidel.

Wimsatt, William C. 1986. "Developmental constraints, generative entrenchment, and the innate-acquired distinction." Pp. 185-208 in P. W. Bechtel (Ed.) Integrating Scientific Disciplines. Dordrecht: Martinus Nijhoff.

Wimsatt, William C. 1987. "False models as means to truer theories." Pp. 23-55 in Matthew H. Nitecki (Ed.) Neutral Models in Biology. Chicago: University of Chicago Press.

Wimsatt, William C. 1997. "Aggregativity: reductive heuristics for finding emergence." Philosophy of Science 64: S372-S384.

Wimsatt, William C. 2000. "Emergence as non-aggregativity and the biases of reductionisms." Foundations of science 5: 269297.

Wimsatt, William C. 2001. "Generative entrenchment and the developmental systems approach to evolutionary processes." Pp. 219-238 in S. Oyama, Paul E. Griffiths and R. D. Gray (Eds.) Cycles of Contingency: Developmental Systems and Evolution. Cambridge, MA: MIT.

Wolpert, Lewis. 1994. "The evolutionary origin of development: cycles, patterning, privilege and continuity." Pp. 79-84 in M. Akam, P. Holland, P. Ingham and G. Wray (Eds.) The Evolution of Developmental Mechanisms. Cambridge: Company of Biologists.

Wolpert, Lewis. 1999. "From egg to adult to larva." Evolution and Development 1: 3-4.

Wright, Sewall. 1918. "On the nature of size factors." Genetics 3: 367 - 374.

Yates, JoAnne A. 1989. Control Through Communication: The Rise of System in American Management. Baltimore: Johns Hopkins University Press.

Zelditch, Miriam L. (Ed.) 2001. Beyond Heterochrony: The Evolution of Development. New York: Wiley. 
Figure 1. Progressive exclusion of the topics comprising evo-devo

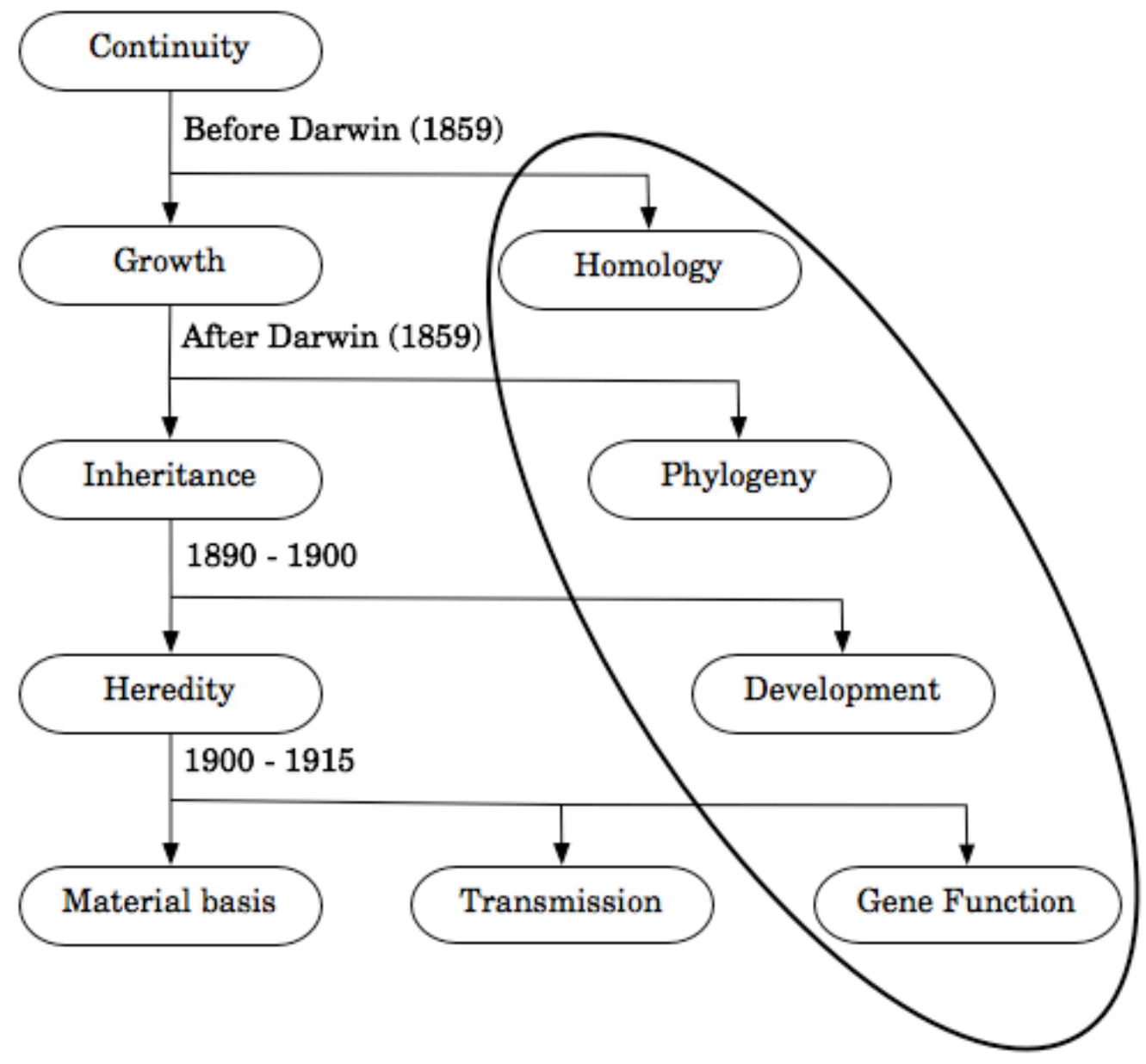


